\title{
USE OF LIQUID FERTILIZER TO REDUCE THE PHYTOTOXIC EFFECTS OF GLYPHOSATE ON EUCALYPTUS ${ }^{1}$
}

\author{
MILER SOARES MACHADO ${ }^{2}$, LINO ROBERTO FERREIRA², JOSÉ LUCAS DE PAULA ${ }^{2}$, GUSTAVO ANTÔNIO \\ MENDES PEREIRA ${ }^{2 *}$, VALDINEI ARAÚJO GONÇALVES ${ }^{2}$
}

\begin{abstract}
Glyphosate is a non-selective herbicide used for weed control in eucalyptus forests. Glyphosate drifts are common and may cause serious damage to crops. An alternative to reduce such effects is to use antidotes capable of protecting eucalyptus. An experiment was conducted to evaluate the effects of the application of liquid fertilizer on eucalyptus plants subjected to a glyphosate drift simulation. The treatments were arranged in a 5 x 5 factorial design. The first corresponding factor was liquid fertilizer $(0,1,2,4$, and $8 \mathrm{~L}$ c.p. ha $^{-1}$ of Fertiactyl Pós $\left.{ }^{\circledR}\right)$ and the second factor dose of glyphosate drift $(0,360,720,1,440$, and 2,160 g e.a. $\left.\mathrm{ha}^{-1}\right)$. The products were applied together so that the spray did not reach the upper third of the plants. At 7, 28, and 49 days after application (DAA), the percentage of intoxication of eucalyptus was evaluated. At 56 days DAA, height, leaf area, leaf nutrient contents, and shoot and root dry matter were determined. Higher doses of glyphosate $\left(1,440\right.$ and 2,160 $\left.\mathrm{g} \mathrm{ha}^{-1}\right)$ caused intoxication levels above $90 \%$ at 28 and 49 DAA without using liquid fertilizer. The combination of $2,160 \mathrm{~g} \mathrm{ha}^{-1}$ of glyphosate with $8.0 \mathrm{~L} \mathrm{ha}^{-1}$ of liquid fertilizer resulted in an estimated eucalyptus dry matter $7 \%$ higher than in the control and $97 \%$ higher than using 2,160 $\mathrm{g} \mathrm{ha}^{-1} \mathrm{of}^{-1}$ glyphosate without the liquid fertilizer. We conclude that the liquid fertilizer was effective in suppressing the harmful effects caused by glyphosate on eucalyptus plants.
\end{abstract}

Keywords: Antidotes. Protectors. Chemical control. Weeds. Application technology.

\section{USO DE FERTILIZANTE LÍQUIDO NA REDUÇÃO DOS EFEITOS FITOTÓXICOS DO GLYPHOSATE NO EUCALIPTO}

\begin{abstract}
RESUMO - O glyphosate é um herbicida não seletivo utilizado no manejo de plantas daninhas em florestas de eucalipto. Problemas com a deriva de glyphosate tem sido comum, podendo causar sérios danos à cultura. Uma alternativa para reduzir estes efeitos é a utilização de antídotos capazes de proteger o eucalipto. Um experimento foi realizado para avaliar os efeitos da aplicação de fertilizante líquido na proteção de plantas de eucalipto submetidas à simulação de deriva de glyphosate. Os tratamentos foram dispostos em esquema fatorial 5 x 5, com o primeiro fator correspondente as o fertilizante líquido $\left(0,1,2,4\right.$ e 8 L p. c. ha ${ }^{-1}$ de Fertiactyl Pós $\left.{ }^{\circledR}\right)$ e o segundo por doses de deriva do glyphosate $\left(0,360,720,1440\right.$ e $2160 \mathrm{~g}$ e. a. ha $\left.{ }^{-1}\right)$. Os produtos foram aplicados juntos de modo que as caldas não atingiram o terço superior das plantas. Aos 7, 28 e 49 dias após a aplicação (DAA) foram avaliadas a porcentagem de intoxicação do eucalipto e aos 56 dias DAA determinou-se a altura, a área foliar, o conteúdo de nutrientes nas folhas e a massa da matéria seca da parte aérea e raízes das plantas. Maiores doses do glyphosate (1440 e $2160 \mathrm{~g} \mathrm{ha}^{-1}$ ) sem o uso do fertilizante líquido provocaram níveis de intoxicação acima de $90 \%$ aos 28 e 49 DAA. A combinação de $2160 \mathrm{~g} \mathrm{ha}^{-1}$ do glyphosate com $8,0 \mathrm{~L} \mathrm{ha}^{-1}$ de fertilizante líquido resultou em estimativa de matéria seca total do eucalipto $7 \%$ maior que a testemunha e $97 \%$ maior que $2160 \mathrm{~g} \mathrm{ha}^{-1}$ de glyphosate sem o fertilizante líquido. Conclui-se que o fertilizante líquido foi eficiente na supressão dos efeitos deletérios causados pelo glyphosate às plantas de eucalipto.
\end{abstract}

Palavras-chave: Antídotos. Protetores. Controle químico. Planta daninha. Tecnologia de aplicação.

\footnotetext{
*Corresponding author

${ }^{1}$ Received for publication in $05 / 18 / 2016$; accepted in $08 / 10 / 2016$.

Paper extracted from the doctoral thesis of the first author.

${ }^{2}$ Department of Plant Sciences, Universidade Federal de Viçosa, Viçosa, MG, Brazil; milermachado@gmail.com, lroberto@ufv.br, joselucasdepaula@gmail.com,gustavogamp@hotmail.com, valdinei.goncalves@ufv.br.
} 


\section{INTRODUCTION}

Glyphosate is the main herbicide used for weed control in eucalyptus crops. It is a systemic and non-selective product used in direct applications through protected bar sprayers or knapsack sprayers. Even if taking due care with the application technology, cases of eucalyptus poisoning caused by an unwanted contact with the herbicide are still frequent. Such contacts occur mainly due to operational difficulties in these applications (TIBURCIO et al., 2012).

An alternative to reduce damage caused by glyphosate is to use antidotes to protect eucalyptus plants. Ray (1984) demonstrated that the addition of valine and isoleucine to herbicide-inhibiting acetolactate synthase (ALS), such as chlorsulfuron, completely reversed the growth inhibition of pea roots (Pisum sativum var. Alaska). Shaner and Reider (1986), using these same amino acids, noted a reversion of the inhibition of growth of corn caused by the herbicide imazapyr. Similarly, Silva et al. (2011), using fluxofenim as a protector of the herbicide S-metolachlor for wheat, observed that the tested cultivar increased its enzymatic activity when this protector was used before herbicide application.

For glyphosate, the addition of aromatic amino acids to the culture medium prevented growth inhibition of B. japonicum, since this microorganism has an enzyme sensitive to glyphosate (SANTOS et al., 2005). The application of sucrose at $2 \%$ to coffee plants one week after glyphosate spraying reversed the toxicity caused by the herbicide (MARTIM, 2003). The use of AminoPlus ${ }^{\circledR}$ (a product based on amino acids; alanine: $1.164 \%$, arginine: $0.189 \%$, aspartic acid: $1.943 \%$, glutamic acid: $3.316 \%$ glycine: $0.202 \%$, isoleucine: $0.171 \%$, leucine:
$0.268 \%$, lysine: $0.240 \%$, phenylalanine: $0.143 \%$, serine: $0.179 \%$, threonine: $0.188 \%$, tryptophan: $0.175 \%$, tyrosine: $0.122 \%$, valine: $0.288 \% ; \mathrm{N}: 11 \%$, and $\mathrm{K}_{2} \mathrm{O}: 1 \%$ ) also reduced the symptoms of glyphosate toxicity in soybeans resistant to glyphosate (ZOBIOLE et al., 2011).

A product with a possible protection effect on eucalyptus plants affected by glyphosate is Fertiactyl Pós ${ }^{\circledR}$ (TIMAC AGRO, 2014). Field reports indicate that this substance has been effective in protecting some crops affected by this herbicide. It is an amino acid-based foliar fertilizer (components not disclosed by the company) whose purpose is to act on the physiological activity of plants while maintaining the ability to produce assimilates.

Although the use of antidotes in the prevention of damage by glyphosate has already been studied for different cultures, there is little information about the application of such products in eucalyptus. Because of the importance of this herbicide to this culture and the operational difficulties in avoiding unwanted contact of glyphosate during applications, effective alternatives are necessary to protect this plant. Thus, the objective of this study is to use liquid fertilizer to protect eucalyptus plants submitted to glyphosate drifts.

\section{MATERIAL AND METHODS}

Standardized eucalyptus seedlings (clone GG100), approximately $30 \mathrm{~cm}$ high, were planted in $10 \mathrm{dm}^{3}$ pots filled with soil from Viçosa, Minas Gerais (MG) state. The soil was corrected and fertilized according to soil analysis (Table 1) and recommendation for the culture.

Table 1. Chemical and physical characteristics of the soil used in the experiment (Viçosa-MG).

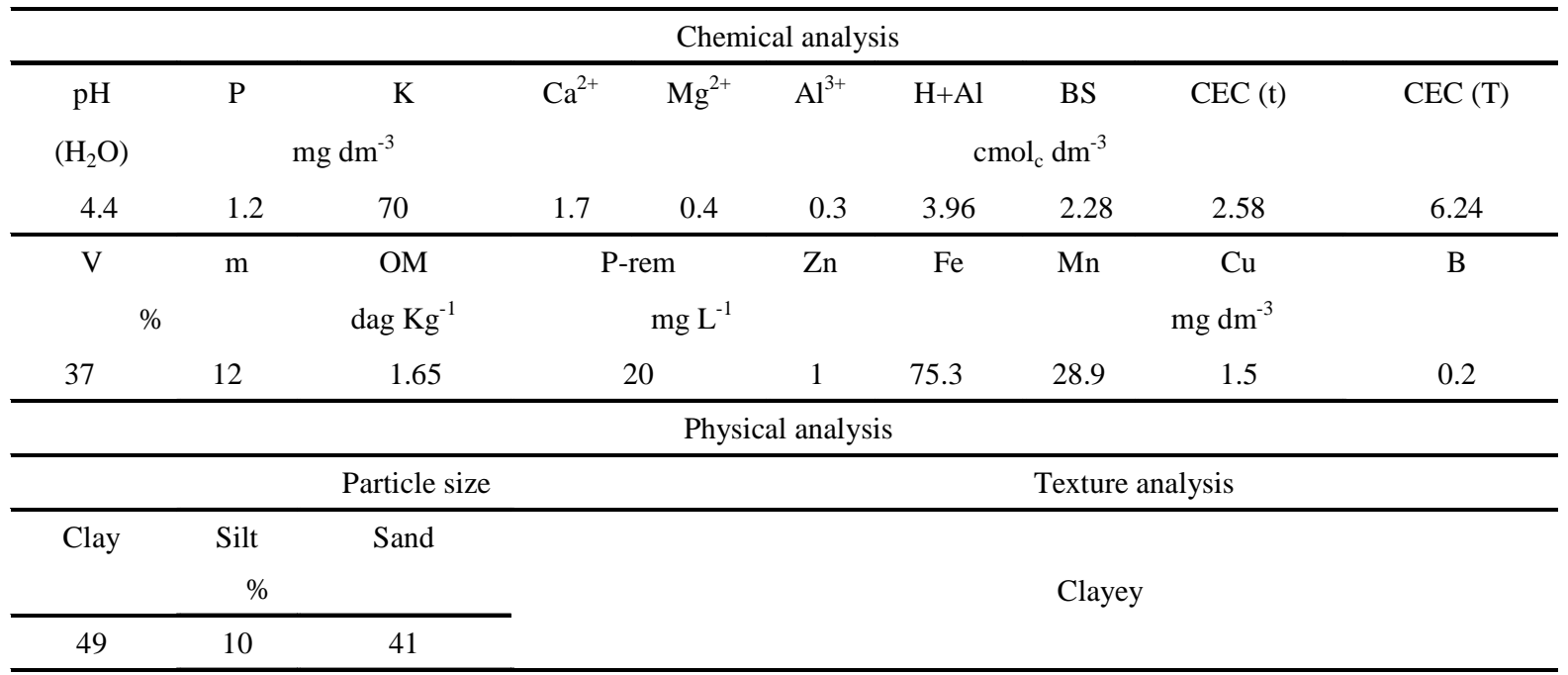

Analysis performed in the Viçosa Soil Analysis Laboratory Ltda. $\mathrm{pH}$ : water, ratio 1:2.5. P-K: Mehlich 1 extractor. Ca-Mg and $\mathrm{Al}$ : KCI extractor - $1 \mathrm{~mol} \mathrm{~L}^{-1}$. H+Al: calcium acetate extractor $0.5 \mathrm{~mol} \mathrm{~L}-1$ - pH 7.0. BS: base sum. CEC (t): Effective cation exchange capacity. CEC (T): cation exchange capacity at $\mathrm{pH}$ 7.0. V: base saturation. M: aluminum saturation. OM: organic matter $=$ C.org x $1.724-$ Walkley-Black. 
The experiment was completely randomized with four replications. Each pot was considered an experimental plot. The treatments were arranged in a $5 \times 5$ factorial design. The first corresponding factor was Fertiactyl Pós ${ }^{\circledR}$ dose $\left(0,1,2,4\right.$, and 8 L c.p. ha $\left.{ }^{-1}\right)$ and the second factor was dose of glyphosate drift $\left(0,360,720,1,440\right.$, and 2,160 g e.a. ha $\left.{ }^{-1}\right)$. Glyphosate doses corresponded, respectively, to 0 , $0.5,1.0,2.0$, and $3.0 \mathrm{~kg} \mathrm{ha}^{-1}$ of the commercial product $\mathrm{Scout}^{\circledR}$.

The liquid fertilizer Fertiactyl Pós® is a product of the TIMAC Agro company, which has the purpose of maintaining a productive gene expression of cultures regarding weed control management and, consequently, product yield. Composed of an organic fraction selected to provide humic and fulvic acids, glycine-betaine and zeatin (GZA complex), and a mineral fraction, the company keeps further information about the product secret.

The treatments were applied 80 days after transplanting the seedlings with the mixture of the product so that the sprays did not reach the upper third of the plants (Figure 1). On this occasion, plants had an average height of $0.60 \mathrm{~m}$ and an average diameter of $7.75 \mathrm{~mm}$.

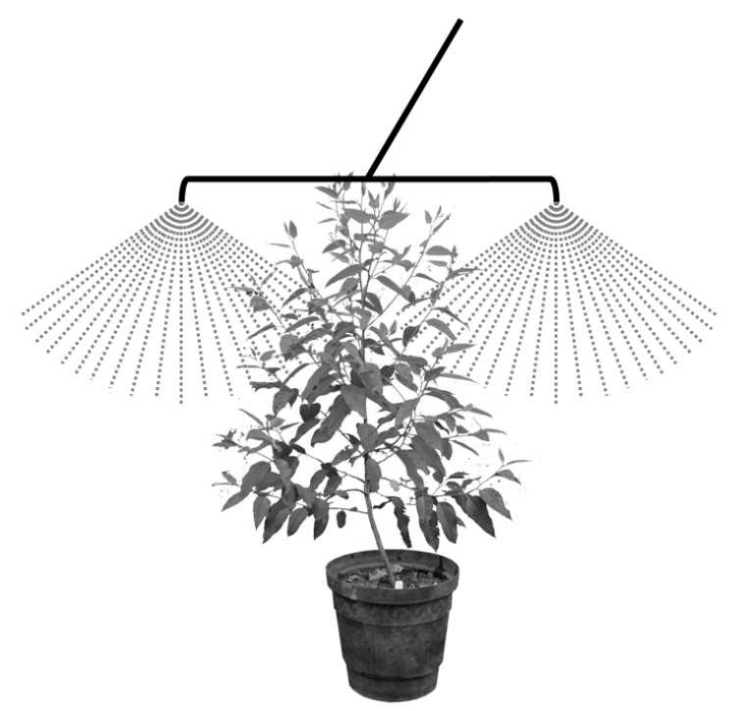

Figure 1. Application of liquid fertilizer and glyphosate to a eucalypt plant.

For the application of the products, a knapsack sprayer pressurized with $\mathrm{CO}_{2}$ was used with a constant pressure of $250 \mathrm{kPa}$. It had two bars containing two TTI 11002 nozzles spaced $0.5 \mathrm{~m}$ apart. The water volume corresponded to $150 \mathrm{~L} \mathrm{ha}^{-1}$. At the time of application, the temperature was $22^{\circ} \mathrm{C}$, relative humidity was $66 \%$, and wind speed was $1.5 \mathrm{~km} \mathrm{~h}^{-1}$. After the application, the leaves of the plants were protected from contact with the irrigation water for 24 hours in order to avoid the washing of the product.

At 7, 28, and 49 days after application (DAA), percentage of intoxication was determined and scores ranging from zero (no symptoms) to one hundred (plant death) were assigned.

At 56 DAA, plant height, shoot and root dry matter, and plant leaf area were evaluated. Measurements were performed using a LI-COR ${ }^{\circledR}$ LI-3100C Area Meter. Separately, stems, leaves, and roots were placed in paper bags and dried in an oven with forced-air circulation $\left(65 \pm 3^{\circ} \mathrm{C}\right)$ until constant mass. After determining the mass of dry matter, leaf nutrient contents were estimated. For this, leaf samples from each plant were collected and submitted to laboratory analysis. After quantification of the contents in the samples, leaf nutrient contents were estimated using the following equation:

$$
\mathrm{C}=(\mathrm{T} \times 10) \times\left(\frac{\mathrm{LDM}}{1000}\right),
$$

where

$\mathrm{C}$ - nutrient content in leaves $\left(\mathrm{g}_{\mathrm{plant}}{ }^{-1}\right)$; $\left.\mathrm{Kg}^{-1}\right)$;

$\mathrm{T}$ - nutrient content in leaves sampled (dag

LDM - leaf dry matter (g plant $\left.{ }^{-1}\right)$.

Eucalyptus poisoning data were analyzed descriptively. Other data were submitted to analysis of variance at $5 \%$ probability; if significant, regression equations were adjusted.

\section{RESULTS AND DISCUSSION}

The liquid fertilizer reduced the toxic effects of glyphosate (Figure 2). Higher doses of glyphosate $\left(1,440\right.$ and 2,160 $\left.\mathrm{g} \mathrm{ha}^{-1}\right)$ caused intoxication levels above $90 \%$ at 28 and 49 DAA without using liquid fertilizer (Figure 3). It is noteworthy that such glyphosate values, although applied only to the base of the plants, do not represent a drift because they are higher than drifts that occur in the field. This 
level of intoxication is extremely harmful to eucalyptus plants. Tuffi Santos et al. (2007), evaluating the effects of glyphosate drift on the growth and wood production of eucalyptus, reported

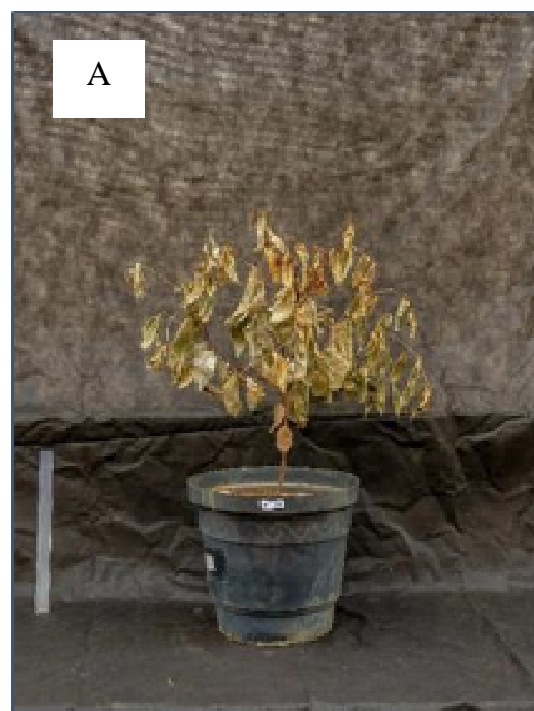

that although visually recovered, plants with intoxication levels above $21 \%$ had a lower estimated timber volume at 360 DAA.

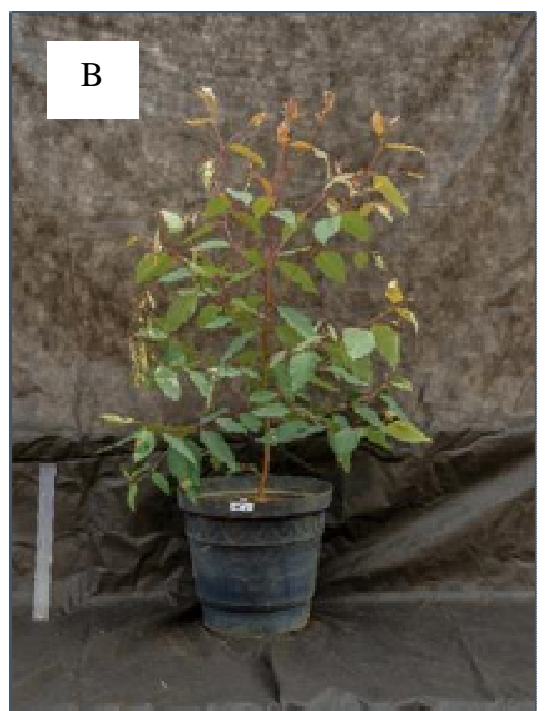

Figure 2. Eucalyptus plants treated with $2,160 \mathrm{~g} \mathrm{ha}^{-1}$ of glyphosate: without liquid fertilizer (A) or mixed with $8 \mathrm{~L} \mathrm{ha}^{-1}$ of liquid fertilizer (B) at 49 DAA.

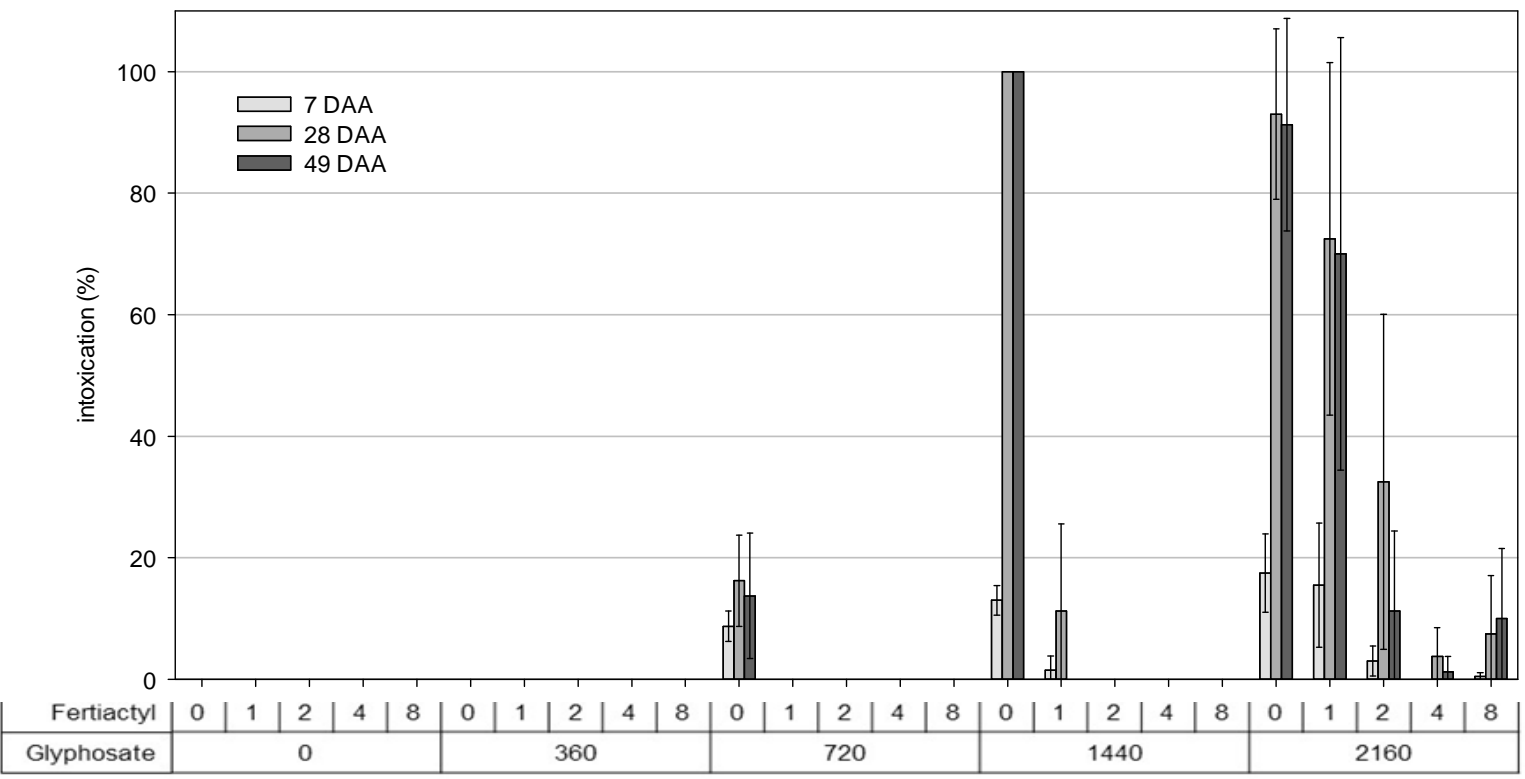

Figure 3. Percentage of intoxication and standard deviations of eucalyptus plants submitted to the application of glyphosate $\left(\mathrm{g} \mathrm{ha}^{-1}\right)$ mixed with liquid fertilizer $\left(\mathrm{L} \mathrm{ha}^{-1}\right)$ at 7,28 , and 49 days after application.

Glyphosate is a systemic and non-selective herbicide. Its mechanism of action is based on the interruption of the shikimic acid pathway responsible for the production of the aromatic amino acids phenylalanine, tyrosine, and tryptophan ((SHANER; LINDENMEYER; OSTLIE, 2012, 2012; FOLONI et al., 2011; YAMASHITA et al., 2009; YAMADA; CASTRO, 2007). Glyphosate causes disturbances in the main metabolic pathways of plants, leading to starvation (MESCHEDE; VELINI; CARBONARI, 2008; TUFFI SANTOS et al., 2007). Thus, it was expected that eucalyptus plants in contact with glyphosate decreased their growth and that the extent of the growth decrease was dependent on the glyphosate dose to which the plant was submitted. This was confirmed in treatments without the use of liquid fertilizer. However, in treatments that used it, the effects of glyphosate were minimized (Figure 4).

Increasing doses of glyphosate, in the absence of liquid fertilizer, damaged the accumulation of total, leaf, stem, and root dry matter (Figure 4). The increase in the dose of liquid fertilizer reduced the 
effects of glyphosate on the accumulation of dry matter in eucalyptus. This decrease is evident in the combination of $2,160 \mathrm{~g} \mathrm{ha}^{-1}$ of glyphosate with $8.0 \mathrm{~L} \mathrm{ha}^{-1}$ of liquid fertilizer, which resulted in an estimated eucalyptus dry matter $7 \%$ higher than in the control $\left(0.0 \mathrm{~g} \mathrm{ha}^{-1}\right.$ of glyphosate and $0.0 \mathrm{~L} \mathrm{ha}^{-1}$ of liquid fertilizer) and $97 \%$ higher than using $2,160 \mathrm{~g} \mathrm{ha}^{-1}$ of glyphosate without liquid fertilizer (Figure 4D). Even the use of the highest dose of
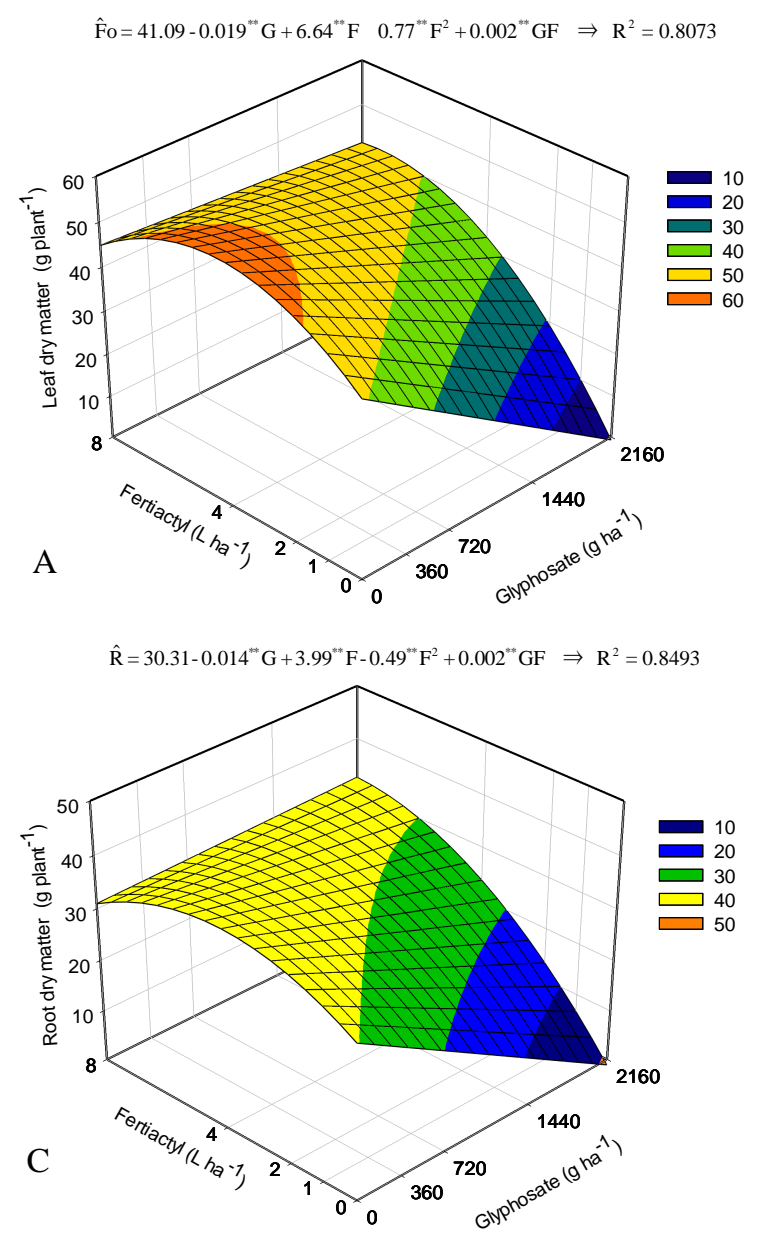

Figure 4. Estimates of masses of leaf dry matter (A), stem dry matter (B), root dry matter (C), and total dry matter (D) $\left(\right.$ g plant $\left.^{-1}\right)$ of eucalyptus plants submitted to application of glyphosate mixed with liquid fertilizer at 56 DAA. The change in color intensity refers to changes in the response variable caused by interaction between these factors.

Leaf area and plant height estimates followed the same tendency as dry matter. The liquid fertilizer reduced the harmful effects of glyphosate on eucalyptus (Figure 5). Regarding leaf area in the absence of glyphosate, the liquid fertilizer dose that resulted in a higher estimate for this characteristic was $4.72 \mathrm{~L} \mathrm{ha}^{-1}$. Using $1,440 \mathrm{~g} \mathrm{ha}^{-1}$ of glyphosate, the liquid fertilizer dose that promoted the greatest leaf area index was $6.26 \mathrm{~L} \mathrm{ha}^{-1}$; for $2,160 \mathrm{~g} \mathrm{ha}^{-1}$, the dose was $7.03 \mathrm{~L} \mathrm{ha}^{-1}$ (Figure 5A). This result shows that the liquid fertilizer dose needed to neutralize the harmful effects of glyphosate on eucalyptus varies glyphosate $\left(2,160 \mathrm{~g} \mathrm{ha}^{-1}\right)$, mixed with doses above $5.76 \mathrm{~L} \mathrm{ha}{ }^{-1}$ of liquid fertilizer, resulted in accumulation of total dry matter of eucalyptus higher than in the control (Figure 4D). Currently, $720 \mathrm{~g} \mathrm{ha}^{-1}$ of glyphosate is the dose widely used for weed management in the forestry sector. Here, $2.19 \mathrm{~L} \mathrm{ha}^{-1}$ of liquid fertilizer are needed to promote an accumulation of dry matter equal to the control at this dose (Figure 4D).

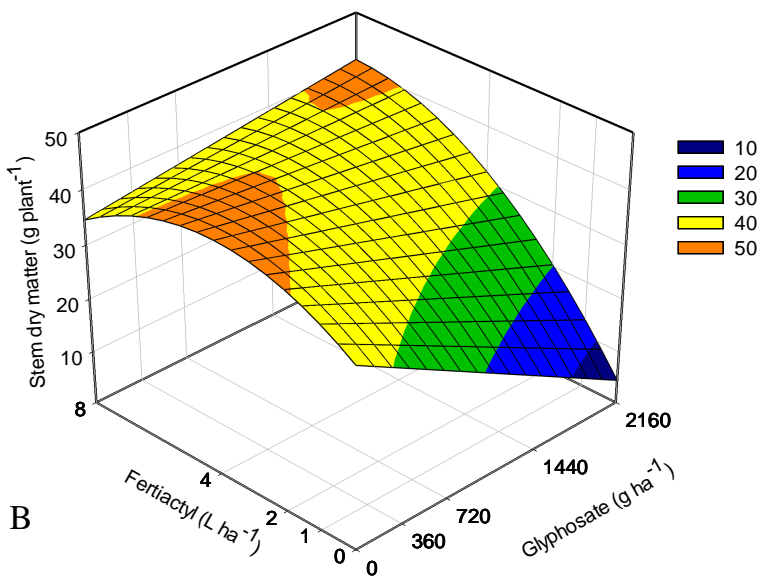

$\hat{\mathrm{T}}=105.22-0.047^{* *} \mathrm{G}+15.09^{*} \mathrm{~F}-1.81^{* *} \mathrm{~F}^{2}+0.006^{* *} \mathrm{GF} \Rightarrow \mathrm{R}^{2}=0.7903$

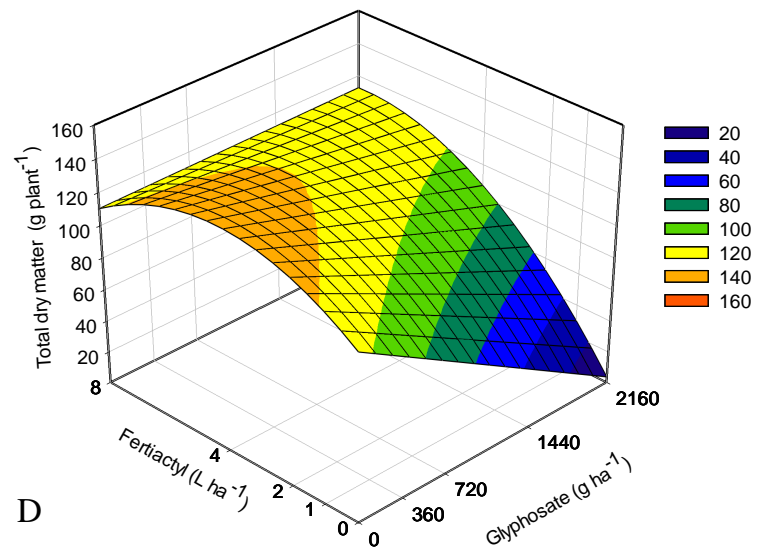



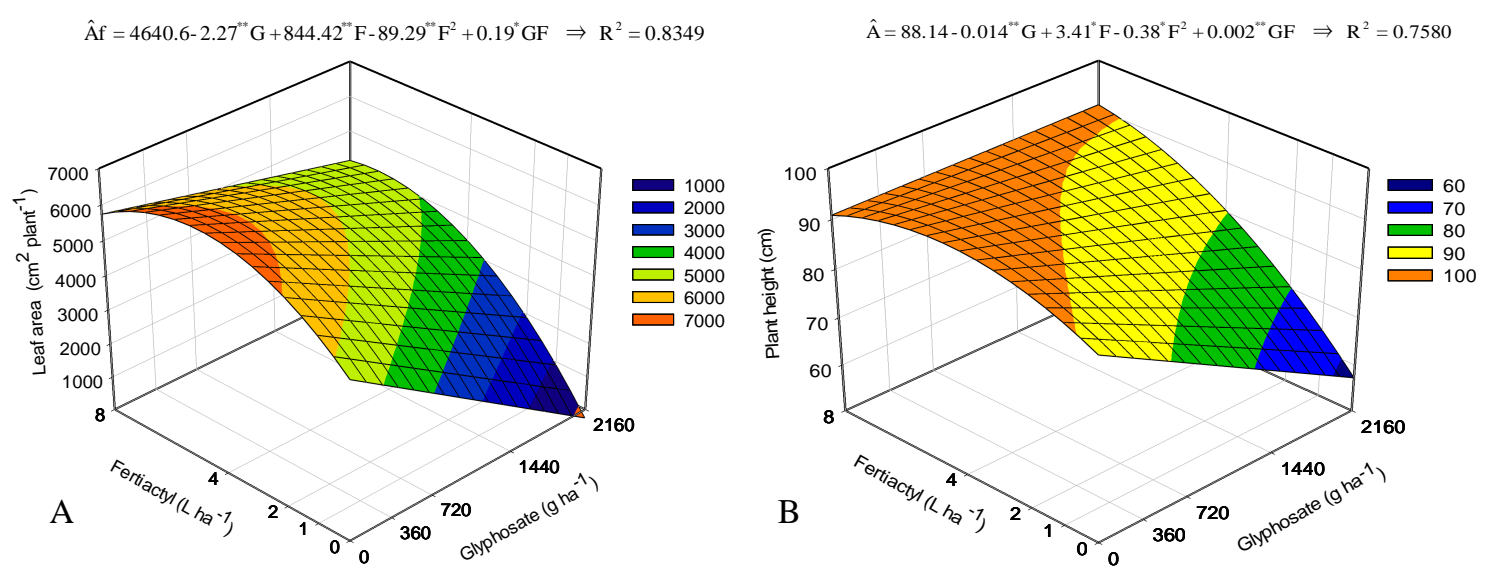

Figure 5. Estimates of leaf area (A) and plant height (B) of eucalyptus plants submitted to the application of glyphosate mixed with liquid fertilizer at 56 DAA. The change in color intensity refers to changes in the response variable caused by the interaction between the factors.
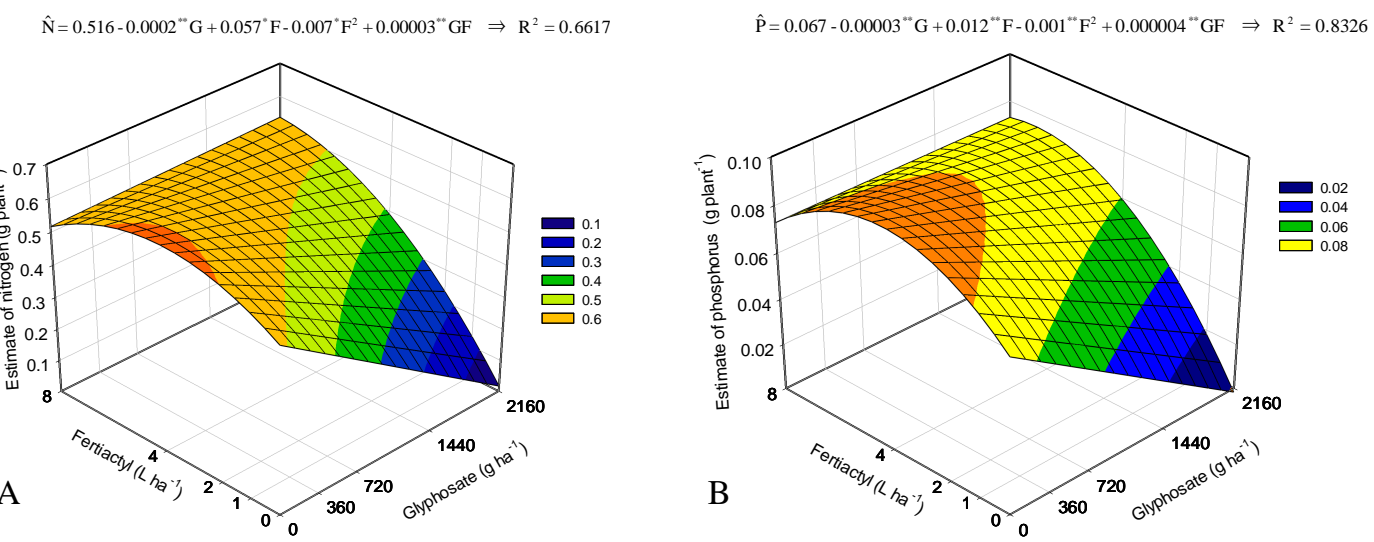

$\hat{\mathrm{K}}=0.287-0.0001^{\prime \prime} \mathrm{G}+0.046^{\prime \prime} \mathrm{F}-0.005^{\prime \prime} \mathrm{F}^{2}+0.00001^{\prime \prime} \mathrm{GF} \Rightarrow \mathrm{R}^{2}=0.8198$ $\hat{\mathrm{C}} \mathrm{a}=0.648-0.0003^{\prime \prime} \mathrm{G}+0.064^{*} \mathrm{~F}-0.008^{*} \mathrm{~F}^{2}+0.00004^{* \prime} \mathrm{GF} \Rightarrow \mathrm{R}^{2}=0.6978$
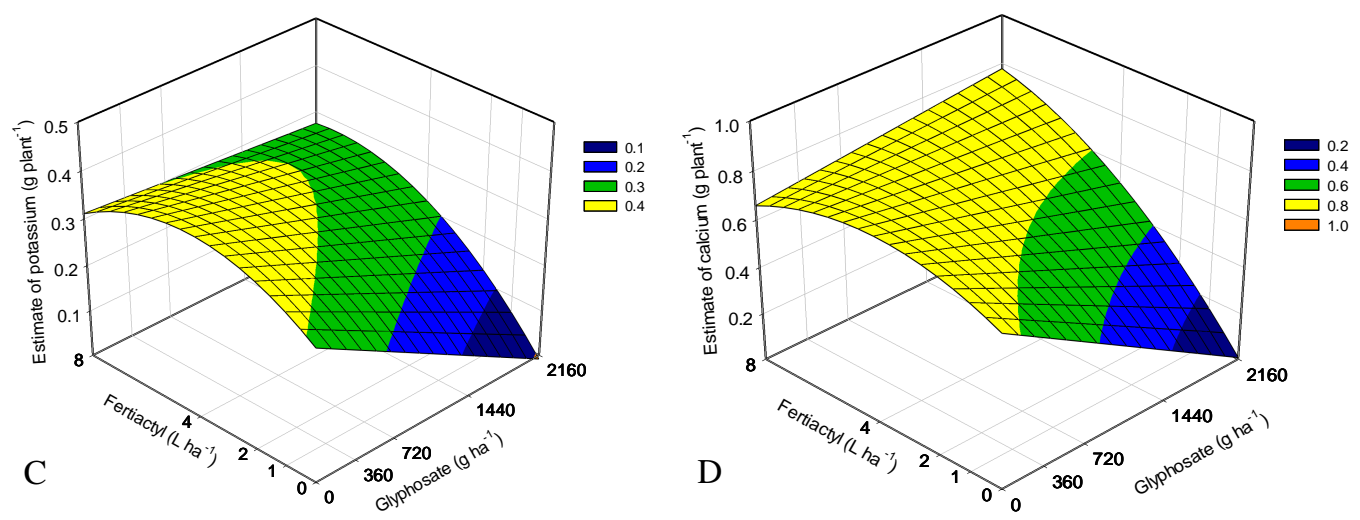

$\hat{\mathrm{M} g}=0.119-0.00005^{*} \mathrm{G}+0.01^{\circ} \mathrm{F}-0.001^{*} \mathrm{~F}^{2}+0.000007^{\prime \prime G F} \Rightarrow \mathrm{R}^{2}=0.7303$

$\hat{S}=0.038-0.00002^{\prime \prime} \mathrm{G}+0.0006^{\prime \prime} \mathrm{F}-0.0006^{\prime \prime} \mathrm{F}^{2}+0.000002^{\prime \prime} \mathrm{GF} \Rightarrow \mathrm{R}^{2}=0.7665$
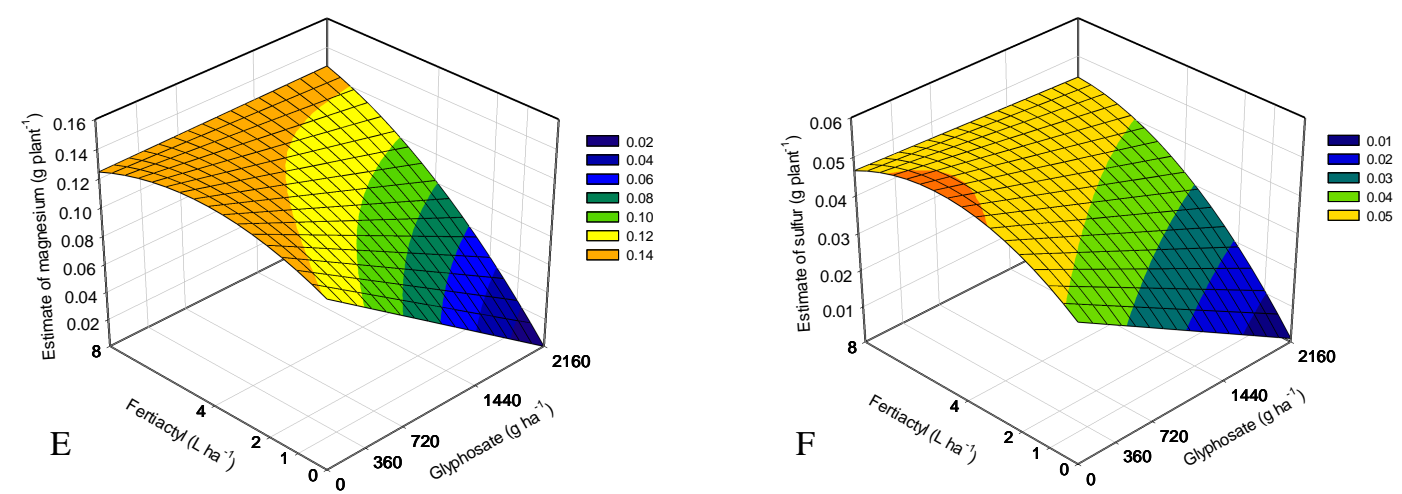

Figure 6. Estimates of nitrogen (A), phosphorus (B), potassium (C), calcium (D), magnesium (E), and sulfur (F) contents in leaves of eucalyptus plants subjected to the application of glyphosate mixed with liquid fertilizer at 56 DAA. The change in color intensity refers to changes in the response variable caused by interaction between these factors. 
Leaf phosphorus content also showed a great increase using liquid fertilizer: from $0.067 \mathrm{~g}$ plant $^{-1}$ in the control treatment to $0.094 \mathrm{~g}^{-1}$ plant $^{-1}$ using 4.0 $\mathrm{L} \mathrm{ha}^{-1}$ of liquid fertilizer without glyphosate (Figure 6B). Among the essential nutrients, phosphorus is of great importance to eucalyptus. It is considered one of the nutrients that limits plant growth the most during early production stages (ROCHA et al., 2013; SILVA et al., 2012; GRACIANO et al., 2006). Because it is present in compounds with a high amount of energy, such as ATP, phosphorus plays a key role in plant life; it is essential for cell division, reproduction, and metabolism (TAIZ; ZEIGER, 2013; MALAVOLTA et al., 1997).

The results of this study show that glyphosate causes nutritional imbalances in eucalyptus. In addition to reducing the productive potential of the plant, such imbalances may cause morphological and biochemical changes and may even make certain genetic materials susceptible to infection by pathogens (SILVEIRA; HIGASHI, 2003). They also demonstrate that the liquid fertilizer, if used at the correct dose, has the potential to minimize such damage can be a growth promoter by acting as foliar fertilizer.

The use of liquid fertilizer mixed with glyphosate was effective in preventing damage to eucalyptus plants caused by the drifts of this herbicide. New research should be conducted to clarify how this product acts in plants and to verify its effect on weed control. Moreover, analysis of the economic viability of using this technology in glyphosate applications is also required regarding the cultivation of eucalyptus.

\section{CONCLUSIONS}

The liquid fertilizer was effective in suppressing the harmful effects of glyphosate on eucalyptus plants affected by this herbicide.

\section{REFERENCES}

FOLONI, J. S. S. et al. Dessecação química em pré-colheita da mamona. Revista Ceres, Viçosa, v. 58, n. 5, p. 665-669, 2011.

GRACIANO, C. et al. Fertilization with phosphorus increases soil nitrogen absorption in young plants of Eucalyptus grandis. Forest Ecology and Management, Amsterdam, v. 236, n. 2-3, p. 202-210, 2006.

MALAVOLTA, E. et al. Avaliação do estado nutricional das plantas: princípios e aplicações. 2 . ed. Piracicaba, SP: Potafós, 1997, 319 p.
MARTIM, S. A. Pulverização do cafeeiro com açúcar: potencial de uso em mudas submetidas à deficiência hídrica e na recuperação de plantas atingidas pelo glifosato. 2003. 67 f. Dissertação (Mestrado em Fisiologia Vegetal) - Universidade Federal de Lavras, Lavras, Lavras, 2003.

MESCHEDE, D. K.; VELINI, E. D.; CARBONARI, C. A. Baixas doses de glyphosate e seus efeitos no crescimento de Commelina benghalensis. Revista Brasileira de Herbicidas, Mossoró, v. 7, n. 2, p. 53-58, 2008.

RAY, T. B. Site of Action of Chlorsulfuron Inhibition of Valine and Isoleucine Biosynthesis in Plants. Plant Physiology, Rockville, v. 75, n. 3, p. 827-831, 1984

ROCHA, J. H. T. et al. Produção e desenvolvimento de mudas de eucalipto em função de doses de fósforo. Cerne, Lavras, v. 19, n. 4, p. 535-543, 2013.

SANTOS, J. B. et al. Tolerance of Bradyrhizobium strains to glyphosate formulations. Crop Protection, Oxford, v. 24, n. 6, p. 543-547, 2005.

SHANER, D. L.; LINDENMEYER, R. B.; OSTLIE, M. H. What have the mechanisms of resistance to glyphosate taught us? Pest Management Science, Hoboken, v. 68, n. 1, p. 3-9, 2012.

SHANER, D. L.; REIDER, M. L. Physiological responses of corn (Zea mays) to AC 243,997 in combination with valine, leucine, and isoleucine. Pesticide Biochemistry and Physiology, San Diego, v. 25 , n. 2 , p. $248-257,1986$.

SILVA, J. R. V. et al. Uso de fluxofenim em trigo como protetor ao herbicida s-metolachlor. Arquivos do Instituto Biológico, São Paulo, v. 78, n. 3, p. 401-407, 2011.

SILVA, M. O. P. et al. Avaliação de dois tratamentos de adubação em plantio de eucalipto clonal em solo arenoso. Bioscience Journal, Uberlândia, v. 28, Sup., p. 212-222, 2012.

SILVEIRA, R. L. V. A.; HIGASHI, E. N. Aspectos nutricionais envolvidos na ocorrência de doenças com ênfase para o eucalipto. Circular Técnica IPEF, Piracicaba, v. 200, n. 1, p. 1-13, 2003.

TAIZ, L.; ZEIGER, E. Plant physiology. 5. ed. Los Angeles, Califórnia: The Benjamin/Cummigs Publishing, 2013. 559 p.

TIBURCIO, R. A. S. et al. Crescimento de mudas de clones de eucalipto submetidos à deriva simulada de diferentes herbicidas. Revista Árvore, Viçosa, v. 36, n. 1, p. $65-73,2012$. 
TIMAC AGRO. Dossiê Fertiactyl Pós ${ }^{\circledR}$ Dossiê

Técnico-Científico. Disponível em: <http://

www.br.timacagro.com/timac/Portugues/

institucional/index.php?acao=detalhar\&cod $=25>$.

Acesso em: 28 abr. 2015.

TUFFI SANTOS, L. D. et al. Crescimento do eucalipto sob efeito da deriva de glyphosate. Planta Daninha, Viçosa, v. 25, n. 1, p. 133-137, 2007.

YAMADA, T; CASTRO, P. R. C. Efeitos do glifosato nas plantas: implicações fisiológicas e agronômicas. INPI - International plant nutrition institute, Peachtree Corners, v. 1, n. 119, p. 1-32, 2007.

YAMASHITA, O. M. et al. Influência do glyphosate e 2,4-D sobre o desenvolvimento inicial de espécies florestais. Scientia Forestalis, Piracicaba, v. 37, n. 84, p. 359-366, 2009.

ZOBIOLE, L. H. S. et al. Prevenção de injúrias causadas por glyphosate em soja RR por meio do uso de aminoácido. Planta Daninha, Viçosa, v. 29, n. 1, p. 195-205, 2011. 